Arab Univ. J. Agric. Sci., Ain Shams Univ., Cairo, Egypt 28(4), 1159-1166, 2020

Website: http://ajs.journals.ekb.eg

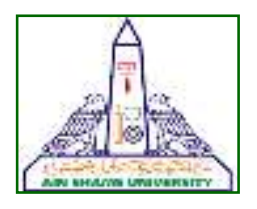

1159

\title{
Evaluation of Microbial Community in Wastewater Treatment Plant Using qRT-PCR Protocol
}

\author{
Sawsan Y Elateek ${ }^{\star}$, Abanob T Sabry, Magdy M \\ Genetic Dept, Fac of Agric, Ain Shams Univ, P.O. 68, Hadayek Shoubra 11241, Cairo, Egypt \\ ${ }^{*}$ Corresponding author: selateek@agr.asu.edu.eg
}

Received 27 September, 2020

Accepted 4 November, 2020

\begin{abstract}
Recycling treated wastewater is considered one of the most critical sectors in recycling. Its benefit fell beyond the disposability of sewage flow that extends to the possibility of reusing the water. Wastewater treatment in any system depends exclusively on maximizing the activity of the microbial community. Wastewater samples were collected from two systems under the same administration in one of the largest wastewater treatment plants (WWTPs) in the Middle East (Al-Jabal Al-Asfar). Five major collection points for the daily assessment of the plant were used for collecting samples. In this study, real-time quantification polymerase chain reaction (qRT-PCR) was used to quantify the microbial community to evaluate the two treatment systems in the plant. Based on the results, the microbial community in each of the five major points from both systems was quantified based on the linear model produced from qRT-PCR. One of the two systems was active and efficient, in contrast to the other, which lacked profound control over the treatment. The current study suggests the routine usage of qRT-PCR as a crucial molecular genetics technique to evaluate the microbial community within the wastewater to ensure reliable and efficient treatment of the raw sewage. The study recommends the full assessment of the inactive system within the plant, encouraging the usage of compatible microbes to enrich and activate the returned activated sludge (RAS) for better performance.
\end{abstract}

Keywords: Wastewater treatment, Plant management, Activated sludge, Microbial community, Absolute quantification, SYBR green

\section{Introduction}

In Egypt, water resources became a necessity due to the rapid population growth and industrial development became necessary especially in areas where the municipal and irrigation water is limited. Furthermore, the amount of wastewater washed out in millions $\left(\mathrm{m}^{3}\right)$, without further usage, impose a considerable problem since its flawed conventional treatment process (Cydzik-Kwiatkowska et al 2012). That is why the reuse of treated wastewaters becomes crucial, despite the growing concern over the quality of its treatment. Moreover, testing the quality of the conventional wastewater treatment process has been long established using different chemical and physical tests, neglecting the microbial load in the process (Cydzik-Kwiatkowska and Zielinska 2016). Indeed, the microbial load in any raw or/and treated wastewater considers a significant indication for the quality of the treatment of the water in removing any contaminants that affect public health and the environment (Cydzik-Kwiatkowska and Zielinska 2016).

Wastewater Treatment Plants (WWTPs) are considered hot spots for the large microbial communities. The levels of some of the microbial load can be accelerated during the treatment of raw wastewater while others decrease.

The wastewater treatment process has been proven to remove various harmful compounds but not effectively (Rizzo et al 2013). Since the quality of the wastewater treatment process depends mainly on the biological activity of the microbial community, it is more feasible to find a reliable method to measure its activity. Daily measurement of certain parameters such as $\mathrm{p}^{\mathrm{H}}$, biochemical oxygen demand (BOD) which measures the amount of 
oxygen consumed by bacteria while its decomposing organic matter, Chemical oxygen demand (COD) which measures the total quantity of oxygen used to oxidize all the organic and inorganic matter, and total dissolved solids (TDS) which is the total concentration of any dissolved organic and inorganic matter of the treated water daily, indicate the efficiency of the treatment of a wastewater plant. Although that might not be sufficient to judge the quality of the treated water considering it is solely based on a biological treatment process (Zhang et al 2020). Usually, the microbial communities within the biological treatment harbor different microbial populations which cannot be detected by the previous mentioned tests (Cydzik-Kwiatkowska et al 2016, Seviour et al 1999). Generally, WWTPs are not evaluated through microbiological tests. That is usually done in external certified laboratories, such as total coliform, fecal coliform counts (MPN), fecal Streptococcus, E. coli, and nematodes; unless the effluent treated wastewater does not meet the standards, at least, for the Egyptian Code for the reuse of treated wastewater in agriculture (501/2005). Besides, the absence of programs onsite to monitor the quality of treated wastewater before reuse; make it harder to allow these untreated waters to pass to the end-users, more importantly, through irrigation.

In WWTP, wastewater characteristics and the type of treatment of plant systems affect quantitative changes between bacterial communities (CydzikKwiatkowska et al 2012, Schramm et al 1999). The quality of wastewater treatment relies on microbial activity and its ability to degrade organic matter. However, chemical and physical tests rather than microbiological tests, are necessary to measure its activity, which are time-consuming (Rittman et al 1999). It is used to monitor the performance of any wastewater treatment system through its activated sludge even though the treatment process relies on the performance of microorganisms biologically. Different methods exist to quantify the microbial community within the wastewater, such as Fluorescence In Situ Hybridization (FISH) (Seviour et al 1999) and blot hybridization (Hall et al 2002). There is a however a need for a rapid and reliable quantitative method to screen for the bacterial communities within the treatment system to provide a new insight for an improved treatment system. Quantified realtime PCR provided reliable quantification of the PCR amplicons of DNA templates isolated from different raw and treated wastewater samples. It is a one single step, where the accumulation of the PCR amplicons is directly monitored during real-time
PCR using a labelled probe and/or SYBR green fluorescence (Becker et al 2000). The cycle thresholds (CT) of each PCR amplicons are compared to a standard curve, resulting in the statistical numerical value of the number of microbial community numbers (quantity) in a given sample.

Therefore, this study aimed to establish a fast, reliable, and cost-effective analytical protocol based on qRT-PCR contrasting two WWTPs $(A)$ and $(B)$. In order to assess and confirm the success of the proposed protocol to measure the quantity of the microbial community as an indicator for the quality of the treated wastewater without the need for further costly microbiological tests.

\section{Materials and Methods}

\subsection{Wastewater Treatment Plant Sampling and Process}

Wastewater samples were collected from two different systems $(A)$ and $(B)$, both under the same administration in one of the largest wastewater treatment plant in Egypt and the Middle East, known as Al-Jabal Al-Asfar (Khanka, Qalyubia Governate). Five significant points were considered: influent (the wastewater flows in the wastewater treatment plant from different locations), return activated sludge (RAS), aeration area (Aer), mechanical dewatering house $(\mathrm{MDH})$, effluent (the treated wastewater flows out from the wastewater treatment plant) from each system, in addition to common stacking area (CSA) from both WWTPs. System (A) was fully operational using international standards and evaluated positively according to the station records, while system (B) was paused for maintenance during sampling and negatively assessed according to the station records).

\subsection{DNA extraction and qRT-PCR Analysis}

Six samples from each system were collected from different stages of the process (influent, effluent, RAS, Aer, MDH and CSA) in sterilized tubes with two replicates from different stages in the plant and were stored in an icebox until being processed in the lab. Water samples were centrifuged at 5000 rpm for $1 \mathrm{~min}$ to precipitate solids and residues. One $\mathrm{ml}$ of each sample and its replicate was used for total DNA extraction, lysozyme $10 \mathrm{ug} / \mathrm{ml}$ was added to each sample and incubated at $36^{\circ} \mathrm{C}$ for $30 \mathrm{~min}$., Trizol solution was added of equal volume in a $2 \mathrm{ml}$ sterilized plastic tubes and incubated at $65^{\circ} \mathrm{C}$ for 30 min., followed by ethanol precipitation and wash 
procedures. Extracted DNA samples then was eluted in $50 \mathrm{ul}$ sterilized water and stored at $-20^{\circ} \mathrm{C}$ before the qRT-PCR run. For each sample (triplicates), 2ul DNA was used as a template to a mixture of 1x SensiFAST Lo-ROX Master Mix with $400 \mathrm{~nm}$ of each primer (928 $F$ 5'-TAA AAC TYA AAK GAA TTG ACG GG-3' and 336 R 5' - ACT GCT GCS YCC CGT AGG AGT CT-3') (Rittman et al 1999). The qRT-PCR thermocycler was programmed as follows: $95^{\circ} \mathrm{C}$ for $10 \mathrm{~min}$ (Enzyme activation), $40 \mathrm{cy}$ cles of two-step program $\left(95^{\circ} \mathrm{C}\right.$ for $10 \mathrm{sec}$. and $60^{\circ} \mathrm{C}$ for $1 \mathrm{~min})$. Ten serial dilutions of counted $E$. colicells (Stock counts $=1.28 \times 10^{5}$ measured at OD600 using SmartSpec Plus Spectrophotometer (Bio-Rad, USA) were amplified under the same conditions to plot the standard curve and estimate the linear regression equation. All counts were calibrated to the dilution factor.

\section{Results and Discussion}

\subsection{Water analysis}

Al-Jabal Al-Asfar, wastewater treatment plant includes sources from daily household activities from most of the Grand Cairo areas. According to the professional assessors of the plant, it has an average flow rate of 1.6 million $\mathrm{m}^{3} /$ day influent. There are standard parameters taken on the site daily such as $\mathrm{p}^{\mathrm{H}}, \mathrm{BOD}, \mathrm{COD}$ and TDS. In the time of the samples collection, these parameters were as follow, average values of $\mathrm{p}^{\mathrm{H}}$ was 7.7-7.8, BOD was 11-13, COD was $36-48$, and total dissolved solids (TDS) was $686-790$ and it seems to match the standard parameters of any household influent flowing into the WWTP (Zhang et al 2020). It has been studied that the ratio between $B O D / C O D$ is the first indication of the water quality and system stability and performance. The ratio of BOD/COD in our WWTP system was 0.3-0.2, while it has been found near 0.5 (Zhang et al 2020) which still was in the range for an influent measurement. The microbial community that is presented in these parameters usually reflects the stability and the efficiency of the plant in the treatment of the wastewater, thus the quality of its effluent (Ahn and Choi 2016).

\subsection{DNA extraction and qRT-PCR assay}

The qRT-PCR assay was conducted on the six samples of collection points from each system in the plant. Furthermore, based on the pre-counted $E$. coli qRT-reactions, $\mathrm{C}_{T}$ values of each concentration sample were used to estimate the linear regression equation. The equation showed a correlation value $\left(R^{2}\right)=0.962$ according to the standard protocol, reflects a reliable standard curve and equation. The equation was set to: $Y=3.445 \times \log (X)+33.34$ with efficiency $=95.1 \%$ Fig 1 .

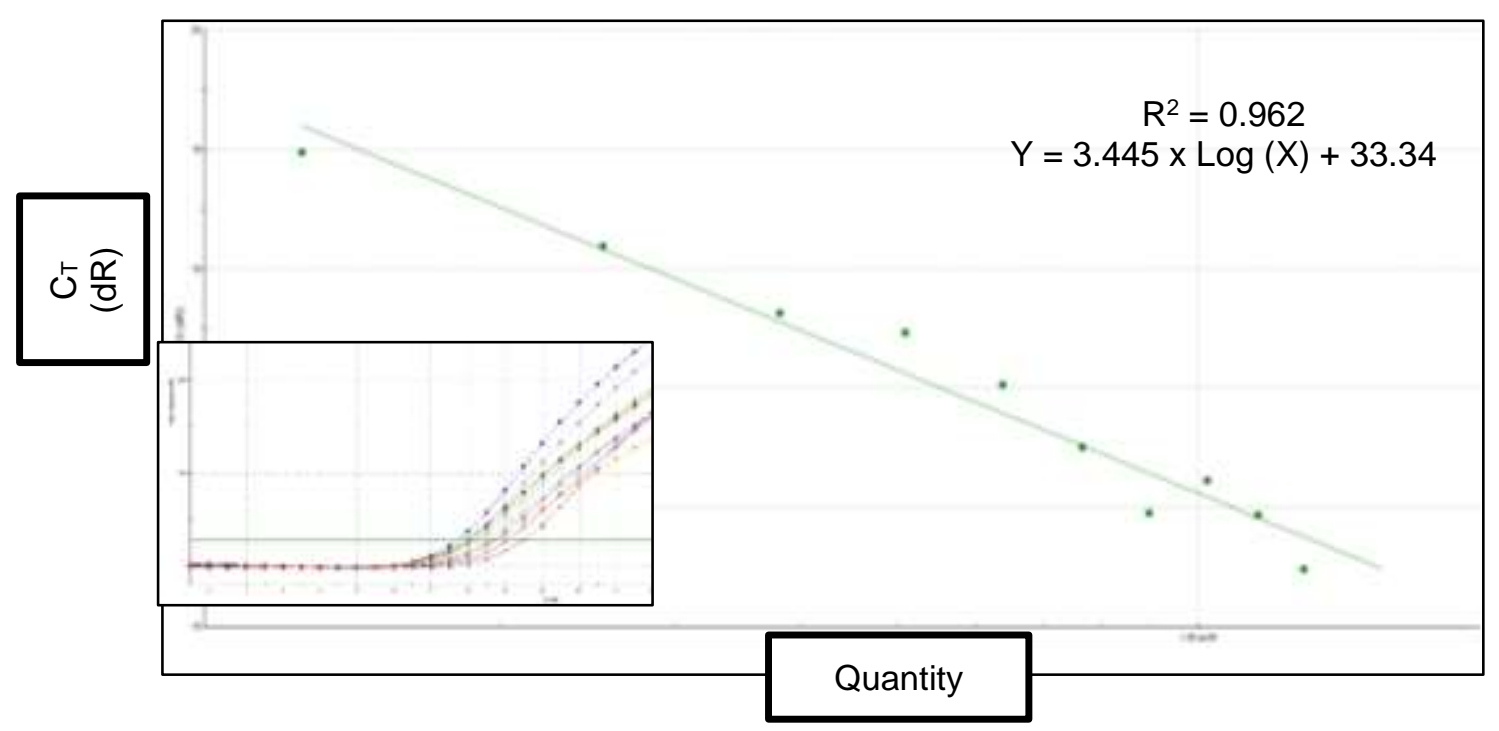

Fig 1. Linear regression equation based on $\mathrm{C}_{\mathrm{T}}$ values 
Higher $\mathrm{C}_{T}$ value represents lower estimated bacterial counts; the MDH sampling point from the system (A) scored the highest $\mathrm{C}_{\mathrm{T}}$ value and recorded the lowest estimated bacterial count, followed by the effluent and the influent, respectively ascending order. The RAS and Aer samples scored the lowest $\mathrm{C}_{\mathrm{T}}$ value and, thus, the highest estimated bacterial count. On the other hand, the MDH from the system (B) showed no $\mathrm{C}_{T}$ value, which means no amplification occurred, while the influent scored the highest bacterial count, followed by the RAS, Aer, and effluent, respectively in descending order. For the CSA, where both systems output, no $\mathrm{C}_{\mathrm{T}}$ value was calculated, which means no bacteria were detected Table 1.

By relatively quantifying each sample using the standard curve, the Influent of System B was higher than System A. In contrast, system A showed much higher quantities of bacterial counts in Aer, RAS, and $\mathrm{MDH}$, while slightly higher in the Effluent samples, while both showed no bacterial count as no $\mathrm{C}_{T}$ values were recorded in the stacking area (CSA) Fig 2. So, even though the bacterial counts of System B were higher, almost double System A in the influent (beginning), but when both systems went through the primary treatment (aeration), System $A$ showed a rapid increase in the bacterial counts compared to System B. Moreover, there was a notable decline in the microbial community in System $B$ through the whole treatment process.

Table 1. Comparison between system (A) and system (B) using $\mathrm{C}_{\mathrm{T}}$ values and relative microbial counts acquired by qPCR analysis.

\begin{tabular}{|c|c|c|c|}
\hline SYSTEM & CODE & C $_{\text {T }}$ & QUANTITY \\
\hline \multirow{4}{*}{ A } & Influent & 19.16 & $9,047,500$ \\
& Aer & 17.73 & $23,045,000$ \\
& RAS & 17.34 & $29,750,000$ \\
& MDH & 27.15 & 48,750 \\
& Effluent & 20.53 & $3,695,000$ \\
\hline \multirow{4}{*}{ B } & Influent & 18.55 & $13,482,500$ \\
& Aer & 20.66 & $3,392,500$ \\
& RAS & 19.71 & $6,315,000$ \\
& MDH & No C & 0 \\
& Effluent & 21.39 & $2,105,500$ \\
\hline A \& B & CSA & No C & 0 \\
\hline
\end{tabular}

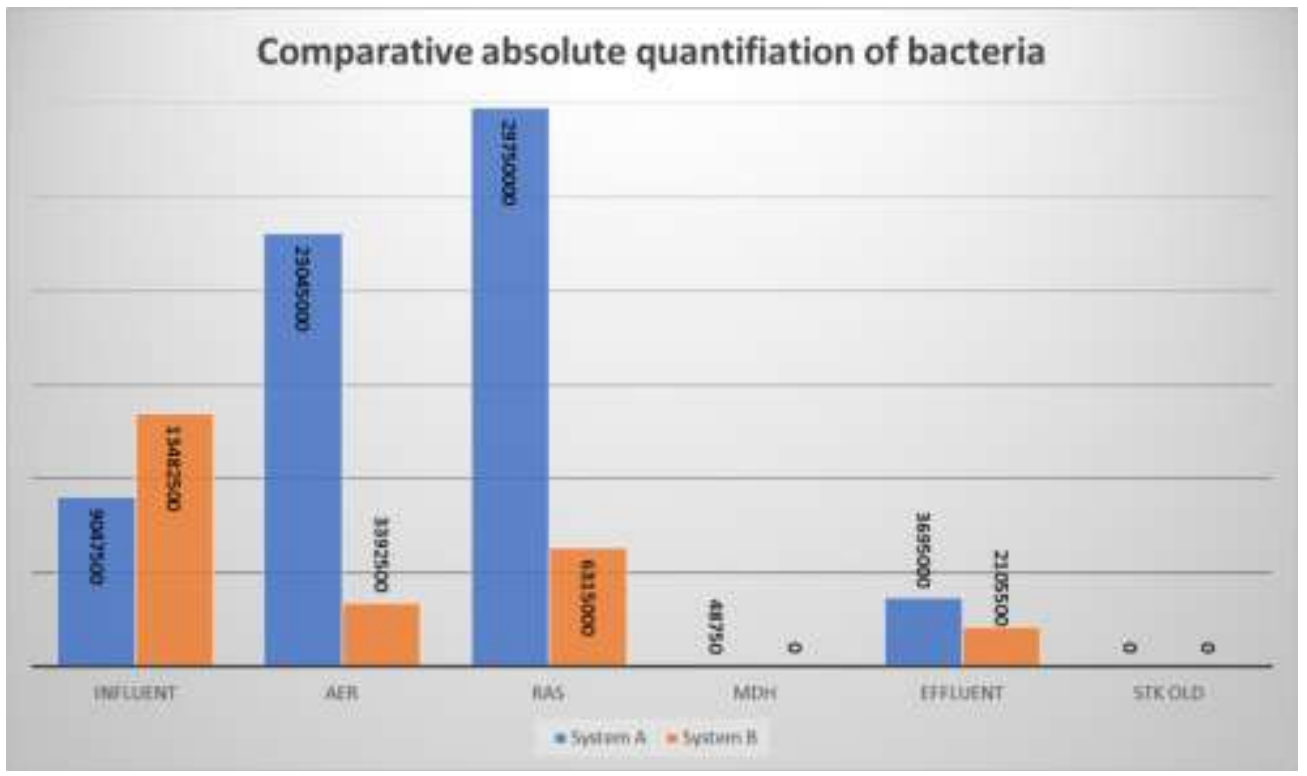

Fig 2. The relative bacterial quantification of both systems (A, blue, and $B$, orange) for the major WWTP points (Influent, Aer, RAS, MDH, Effluent, and CSA). 

QRT-PCR Protocol

The result of the qRT-PCR analysis shows one system $(A)$ has an active microbial community in return activated sludge (RAS) and aeration area (Aer), while the other system (B) showed inactive microbial community in both areas. It is an alarming indication of the performance of System B; even though the bacterial count at the beginning of the influent was high, but it went down in quantity once the primary treatment started.

In WWTPs, quantitative changes between bacterial communities are affected by wastewater characteristics and the type of operation of the treatment system (Cydzik-Kwiatkowska et al 2012, Hall et al 2002, Seviour et al 1999). The usage of qRT-PCR has allowed quantitative analysis of DNA templates, representing microbial communities count within the raw and treated wastewater and monitoring the progress of each step/ process along the way of wastewater treatment to ensure the safety of the plant, quality of effluent, and the system performance. The load of the microbial community in any WWTPs depends on the influent wastewater. However, it is almost unfeasible to rely on conventional microbiological techniques to detect the lower microbial community in RAS and Aer in System (B), which might take more than a week to get its results back from the lab. Only quantitive measures like qRT-PCR can guide the assessment through the quality of wastewater treatment with the presence of microbial communities (Biesterfeld et al 2001, La Para et al 2000, Onuki et al 2000). Price et al (2018) used analytical chemistry and qRT-PCR to monitor the microbial communities in a wastewater treatment plant in six sites along the Wissahickon Creek, which helped to estimate the high-quality effluent that was discharged from WWP to the Schuylkill River as a drinking water resource in eastern Pennsylvania.

Finding molecular genetics techniques that allow a sensitive yet precise detection of the microbial community in the wastewater consider a faster way to quantify and monitor the quality of wastewater treatment than the classical approaches since the time and efficiency are the most important aspects of any WWTP. (Koch et al 2000). One of the first techniques tried to establish this approach was FISH technique that was used to quantify the bacterial community in any given WWTP (Sanz and Köchling 2007). However, due to its limitation to study only the nitrification bacteria such as ammonia-oxidizing bacteria (AOB), it failed to detect the total bacterial community in any WWTP system. Wong et al (2005) used the FISH technique to investigate the bacterial community in different
WWTPs. The results concluded that there is no a low association between the presence of the bacterial community and the performance of the wastewater system.

Moreover, Rowan et al (2003) used conventional PCR to compare the diversity and community of different $(A O B)$ in multiple full-scale wastewater treatment reactors. The counts of bacteria were different in each treatment section of each reactor, in which they did estimate their relativeness but could not judge the performance of the reactors. At the same time, Zhang et al (2020) used the ratio between BOD/COD as an indispensable index to assess system performance and indicate an impending process that took so long to measure.

Detecting the efficiency of the treatment of wastewater plant is considered a priority when it comes to the availability of this water for irrigation or drinking water. There is a real struggle with the absence of a program to monitor the quality of reclaimed (effluent) wastewater before and after treatment, which is necessary before discharging these waters onto a public network of irrigation or drinking water companies. Furthermore, if we need to improve the quality of the treated wastewater, we need a fast and efficient method to monitor the wastewater quality and the microbial communities that control it. Therefore, the application of such a technique like qRT-PCR allows a better understanding of the link between microbial community and operation of the plant system through observing the rapid changes within the microbial community along the treatment process (Cydzik-Kwiatkowska et al 2012, La Para et al 2000, Limpiyakorn et al 2006). That is why our study focused on evaluating the quantity of the microbial community in both systems ( $A$ and $B$ ) using the qRT-PCR technique to measure the quality of the treated wastewater and the system performance.

\section{Conclusion}

It was concluded that using qRT-PCR used in this study as a quantitative method is sensitive, efficient, and reliable enough to detect any problem in any step along the wastewater treatment process. As it was successfully measured every step of the treatment in both system in the real time, with no complications or contamination or delay to wait for the results. In addition to, it can be repeated daily in both systems using small amount of each sample. It gave an insight about the defect in system (B) compared to system $(A)$ as it is crucial to fix any problem 
that faces any system before it fails to treat the water and could cause more damage through releasing effluent with untreated wastewater from WWTP. Therefore, it is convenient to be used regularly on the daily assessment of the wastewater to determine the quality of the treatment of the wastewater system.

\section{Competing Interests}

The authors declare no conflict of interest.

\section{References}

Ahn, Y; Choi, J (2016) Bacterial Communities and Antibiotic Resistance Communities in a Full-Scale Hospital Wastewater Treatment Plant by HighThroughput Pyrosequencing. Water 8, 580. 10.3390/w8120580.

Becker, S; Boger, P; Oehlmann, R; Ernst, A (2000) PCR Bias in ecological analysis: a case study for quantitative Taq-nuclease assays in analyses of microbial communities. Appl Environ Microbiol 66, 4945-4953.

Biesterfeld, S; Figueroa, L; Hernandez, M; Russell, P (2001) Quantification of Nitrifying Bacterial Populations in a Full-Scale Nitrifying Trickling Filter Using Fluorescent in Situ Hybridization. Water Environment Research 73, 329-338.

Cydzik-Kwiatkowska, A; Zielin'ska, M; Wojnowska, B (2012) Impact of operational parameters on bacterial community in a full-scale municipal wastewater treatment plant. Pol J Microbiol 61, 4149.

Cydzik-Kwiatkowska, A; Zielinska, M (2016) "Bacterial communities in full-scale wastewater treatment systems". World J Microbiol Biotechnol 32, 66.

Hall, SJ; Hugenholtz, P; Siyambalapitiya, N; Keller, J; Blackal, LL (2002) The development and use of real-time PCR for the quantification of nitrifiers in activated sludge. Water Sci and Technology 46, 267272.

Koch, G; Egli, K; Van der Meer, JR; Siegrist, H (2000) Mathematical modeling of autotrophic denitrification in a nitrifying biofilm of a rotating biological contactor. Water Sci Technol 41, 191-198.doi: https://doi.org/10.2166/wst.2000.0444
La Para, TM; Nakatsu, CH; Pantea, L; Alleman, JE (2000) Phylogenetic analysis of bacterial communities in mesophilic and thermophilic bioreactors treating pharmaceutical wastewater. Appl Environ Microbiol 66, 3951-3959.

Limpiyakorn, T; Kurisu, F; Yagi, O (2006) Development and application of real-time PCR for quantification of specific ammonia-oxidizing bacteria in activated sludge of sewage treatment plants. Appl Genet Mol Biotechnol 7, 1004-1013.

Onuki, M; Sato, H; Mino, T; Matsuo, T (2000) Application of molecular methods to microbial community analysis of activated sludge. Water Sci Technol 42. doi:10.2166/wst.2000.0353.

Price, JR; Ledford, SH; Ryan, MO; Toran, L; Sales, CM (2018) Wastewater treatment plant effluent introduces recoverable shifts in microbial community composition in receiving streams. Sci Total Environ 1104-1116. doi:10.1016/j.scitotenv.2017.09.162

Rittman, BE; Laspiduo, CS; Flax, J; Stahl, D; Urbain, V; Harduin, H; van der Waarde, JJ; Geurkink, B; Henssen, MJC; Brouwer, H; Klapwijk, A; Wetterauw, M (1999) Molecular modelling analysis of the structure and function of nitrifying activated sludge. Wat Sci Tech 39, 51-59.

Rizzo, L; Manaia, C; Merlin, C; Schwartz, T; Dagot, C; Ploy, MC; Michael, I; Fatta-Kassinos, D (2013) Urban wastewater treatment plants as hotspots for antibiotic resistant bacteria and genes spread into the environment: A Review Sci Total Environ 447, 345-360.

Rowan, AK; Snape, JR; Fearnside, D; Barer, MR; Curtis, TP; Head, IM (2003) Composition and diversity of ammonia-oxidizing bacterial communities in wastewater treatment reactors of different design treating identical wastewater. FEMS Microbiol Ecol 43,195-206.

Sanz, J; Köchling, T (2007) Molecular Biology Techniques Used in Wastewater Treatment: An Overview. Process Biochemistry 42, 119-133. doi:10.1016/j.procbio.2006.10.003.

Schramm, A; de Beer, D; van den Heuvel, JC; Ottengraf, S; Amann, R (1999) Microscale distribution of populations and activities of Nitrosospira and Nitrospira spp. along a macroscale gradient in a nitrifying bioreactor: Quantification by in situ hybridization and the use of microsensors. Appl Environ Microbiol 65, 3690-3696. 
QRT-PCR Protocol

Seviour, RJ; Lindrea, KC; Griffiths, PC; Blackall, LL (1999) The activated sludge process. In: Seviour RJ and Blackall LL (eds.). The Microbiology of Activated Sludge, Kluwer Academic Publishers, Netherlands pp 44-75.

Wong, MT; Mino, T; Seviour, RJ; Onuki, M (2005) In situ identification and characterization of the microbial community structure of full-scale enhanced biological phosphorus removal plants in Japan Water Res 39, 2901-2914.
Youngho, A; Jeongdong, C (2016) Bacterial Communities and Antibiotic Resistance Communities in a Full-Scale Hospital Wastewater Treatment Plant by High-Throughput Pyrosequencing. Water 8, 111.

Zhang, B; Ning, D; Yang, Y; Van, NJ; Zhou, J; Wen $X$ (2019) Biodegradability of wastewater determines microbial assembly mechanisms in full-scale wastewater treatment plants. Water Res 169, 115276. doi: 10.1016/j.watres.2019.115276.

Zhang, T; Shao, MF; Ye, L (2012) 454 Pyrosequencing reveals bacterial diversity of activated sludge from 14 sewage treatment plants. ISME $J$ 6, 1137-1147. 


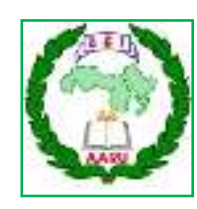

مجلة اتحاد الجامعات العربية للطوم الزراعية، جامعة عين شمس، القاهرة، مصر

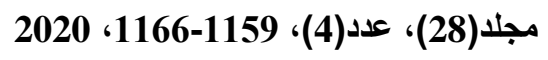

1166

Website: http://ajs.journals.ekb.eg

[82]

\author{
سوسن يوسف العتيق" - ابانوب ثروت صبري - محمود مجدي \\ قسم الوراثة - كلية الزراعة - جامعة عين شمس - ص.ب 68 - حدائق شبرا 11241 - القاهرة - مصر مبرد مبري
}

*Corresponding author: selateek@agr.asu.edu.eg

Received 27 September, 2020

Accepted 15 November, 2020

الحِمل الميكروبى فى الخمس مناطق الكبرى فى كلا النظامين داخل المحطة إعتماداً على النموذج الخطي الخطى فئ

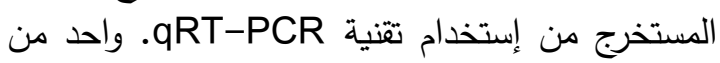
النظامين كان يعمل بصورة فعَّالة ونشطة على العنى العكس

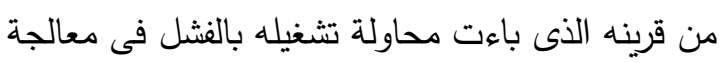

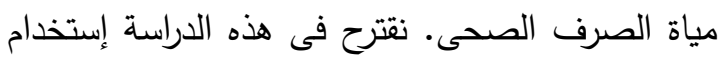

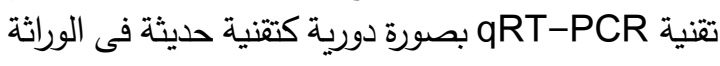

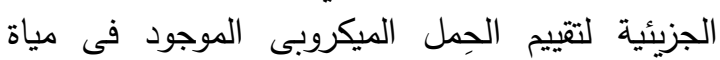
الصرف الصحى حيث يعتبر طريقة موثوق بها وفعَّالة

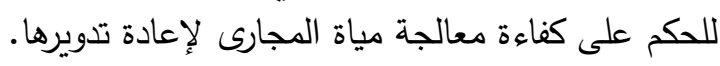

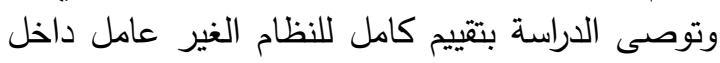

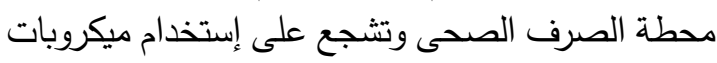

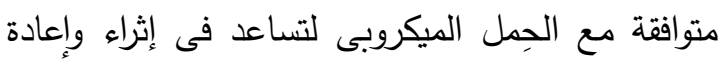
تتشيط الحمأة المنشطة لتحسين آداء هذا النظام.

تعتبر إعادة تدوير مياه الصرف واحدة من أهم الهم

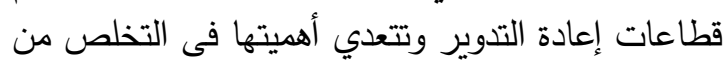

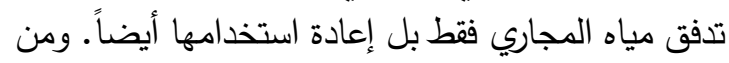

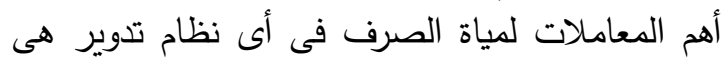

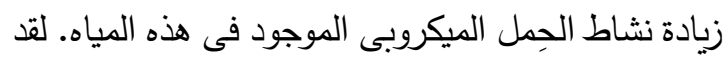

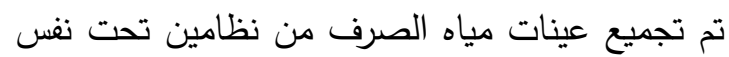
الإدارة فى واحدة من أكبر محطات مياه الصرف الصنات الصحي

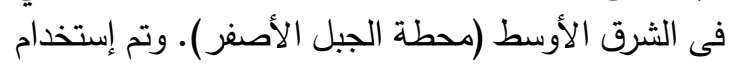

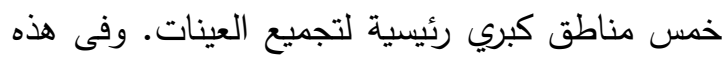

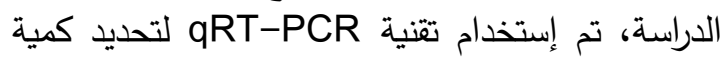

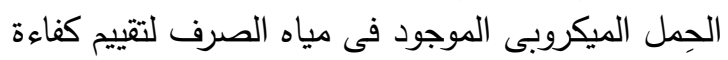
كلا النظامين فى محطة الصرف الصود في الصحى. فتم تثييم 